\title{
High salicylic acid concentration alters the electron flow associated with photosystem II in barley
}

\author{
Ghader HABIBI $^{1^{*}}$, Atousa VAZIRI ${ }^{1}$
}

Received February 09, 2017; accepted May 08, 2017.

Delo je prispelo 09. februarja 2017, sprejeto 08. maja 2017.

\begin{abstract}
In this study, the effects of exogenously applied salicylic acid (0.5 and $5 \mathrm{mM} \mathrm{SA})$ on the rates of photosystem II (PSII) activity was analysed in 4-week-old barley (Hordeum vulgare Bahman') seedlings using chlorophyll (Chl) a fluorescence transient $(O J I P)$ measurements. No evident changes in Chl and carotenoid contents as well as chlorophyll fluorescence transient curves were observed in either of the studied concentrations after $24 \mathrm{~h}$ of SA application. After $5 \mathrm{~d}$, low SA concentration $(0.5 \mathrm{mM})$ increased PSII activity, Chl $b$ and carotenoid contents in barley seedlings. In contrary, 5 days after $5 \mathrm{mM} \mathrm{SA}$ treatment, the maximal quantum efficiency of PSII $\left(F_{\mathrm{v}} / F_{\mathrm{m}}\right)$ and the Performance Index $\left(\mathrm{PI}_{\mathrm{ABS}}\right)$, as an indicator of PSII structure and functioning, were significantly decreased. This lower $F_{\mathrm{v}} / F_{\mathrm{m}}$ and $\mathrm{PI}_{\mathrm{ABS}}$ coupled with lower levels of $\mathrm{Chl} b$ and carotenoids, and lower values of photosynthetic electron transport chain components including the electron transport flux $\left(\varphi \mathrm{E}_{\mathrm{o}}\right)$ and the inferred oxygen evolving complex activity $\left(F_{\mathrm{v}} / F_{\mathrm{o}}\right)$. By monitoring the chlorophyll $a$ fluorescence rise kinetics, from the initial " $O$ " level to the " $P$ " (the peak) level, a dramatic increase in "OJ" phase was detected, which coincides with an increased photoreduction of $\mathrm{Q}_{\mathrm{A}}$ as a result of blockage of electron flow. This study provided the evidence that the high concentration of SA induced damage to different sites of the PSII.
\end{abstract}

Key words: photosynthetic pigments; photosynthetic electron flow; Hordeum vulgare 'Bahman'; OJIP transient flourescence; salicylic acid

IZVLEČEK

\section{VELIKA KONCENTRACIJA SALICILNE KISLINE SPREMINJA PRI JEČMENU FOTOSINTEZNI, S FOTOSISTEMOM II POVEZAN ELEKTRONSKI PRETOK}

$\mathrm{V}$ raziskavi so bili preučevani učinki dodajanja salicilne kisline (0.5 in $5 \mathrm{mM}$ ) na aktivnost fotosistema II (PSII) pri 4tedne starih kalicah ječmena (Hordeum vulgare'Bahman') z meritvami fluorescence $(O J I P)$ klorofila a (Chla). Nobenih sprememb v vsebnosti klorofila in karotenoidov kot tudi ne sprememb v fluorescenci ni bilo opaznih po 24 urah dodajanja obeh koncentracij salicilne kisline. Po petih dneh so se $\mathrm{v}$ kalicah ječmena pri dodani manjši koncentraciji salicilne kisline $(0.5 \mathrm{mM})$ povečali aktivnost PSII, vsebnost $\mathrm{Chl} \mathrm{b}$ in karotenoidov. Nasprotno sta se pet dni po obravnavanju s 5 $\mathrm{mM}$ salicilno kislino značilno zmanjšala učinkovitost PSII $\left(F_{\mathrm{v}} / F_{\mathrm{m}}\right)$ in $\mathrm{PI}_{\mathrm{ABS}}$ indeks kot indikatorja zgradbe in delovanja PSII. Zmanjšanje $F_{\mathrm{v}} / F_{\mathrm{m}}$ in $\mathrm{PI}_{\mathrm{ABS}}$ je bilo povezano $\mathrm{z}$ zmanjšanjem vsebnosti klorofila $b$ in karotenoidov ter $\mathrm{Z}$ manjšimi vrednostimi komponent fotosintezne elektronske verige, vključno $\mathrm{s}$ elektronskim pretokom $\left(\varphi \mathrm{E}_{\mathrm{o}}\right)$ in $\mathrm{z}$ njim povezano aktivnostjo kompleksa, ki sprošča kisik $\left(F_{\mathrm{v}} / F_{\mathrm{o}}\right)$. Pri spremljanju povečanja fluorescence klorofila a od začetne " $O$ " na največjo vrednost " $P$ " je bilo opazno njeno dramatično povečanje $\mathrm{v}$ fazi " $O J$ ”, kar je soupadalo s povečano fotoredukcijo $\mathrm{Q}_{\mathrm{A}}$ kot posledica blokade fotosintezenega elektronskega pretoka. Raziskava dokazuje, da večja koncentracija salicilne kisline povzroči poškodbe na večih mestih PSII.

Ključne besede: fotosintezna barvila; fotosintezni elektronski pretok; Hordeum vulgare 'Bahman', OJIP prehodna fluorescenca; salicilna kislina

\footnotetext{
1* Corresponding author: Associate Prof. Dr. Ghader Habibi, Biology Department, Payame Noor University, PO BOX 19395-3697 Tehran, Iran, Telephone: +98 482322 2702, Fax: +98 422822 8055, Email: gader.habibi@gmail.com

1 Department of Biology, Payame Noor University (PNU), Iran
} 


\section{INTRODUCTION}

Salicylic acid (SA), as a common plant-produced phenolic compound, plays an important role in plant growth and development as well as in tolerance to biotic and abiotic stresses (Li et al., 2014; Khan et al., 2014; Janda and Ruelland, 2015). In recent years the involvement of SA in the plant growth and yield (Javaheri et al., 2012), and the regulation of some photosynthetic reactions (Arfan et al., 2007; Li et al., 2014) has widely been studied.

It has been suggested that the effects of SA on plant physiological and biochemical processes depends on the concentration of the applied SA (Miura and Tada, 2014). At low concentrations $(0.1-0.5 \mathrm{mM}$ for most plants), it enhances the efficiency of the antioxidant system and the efficiency of PSII photochemistry (Chen et al., 2016), whereas at higher concentrations (1-10 $\mathrm{mM}$ for most plants) it increases oxidative damage (Hara et al., 2012; Miura and Tada, 2014). Although negative effect of SA is probably correlated with an imbalance in antioxidant metabolism (Hasanuzzaman et al., 2013), the specific mechanisms of SA-mediated damages remain elusive. It is assumed that, plants respond to high SA depend on PSII response to this stress (Chen et al. 2016). To address this issue, the chlorophyll (Chl) $a$ fluorescence transient (OJIP) measurements were used to study photosynthetic apparatus functioning in response to various SA concentrations and incubation times in this study.

Chl $a$ fluorescence induction (OJIP, where $O$ (or $F_{\mathrm{o}}$ ) is the minimum fluorescence when all $\mathrm{Q}_{\mathrm{A}}$ (the primary quinone acceptor of PSII) are in the oxidized state, $P$ (or $\left.F_{\max }\right)$ is the maximal fluorescence when all $\mathrm{Q}_{\mathrm{A}}$ is in the reduced state $\left.\left(\mathrm{QA}^{-}\right)\right)$has been studied extensively in photosynthesis physiology research (Jee, 1995; Kalaji et al., 2011; Hamdani et al., 2015). The reduction of $\mathrm{Q}_{A}$ by PSII causes chlorophyll $a$ fluorescence to rise from its minimal fluorescence level " $O$ " to a " $J$ " level (or $F_{\mathrm{J}}$ ). Fluorescence rise from " $J$ " level to the " $I$ " level ( or $F_{\mathrm{I}}$ ) is related to the filling up of the plastoquinone pool. Finally, a traffic jam of electrons on the electron acceptor side photosystem I generates a fluorescence rise from the " $P$ " level to the " $P$ " level. The analysis of chlorophyll $a$ fluorescence signals using 'JIP-test', explores the information about the structure and function of the photosynthetic apparatus mostly related to PSII (Strasser et al., 2000; Bussotti et al., 2007) as well as some parameters due to energy fluxes for light absorption (ABS), trapping (TR) of excitation energy and electron transport (ET) per reaction center (RC) or per sample area called cross-section (CS) (Strasser et al., 2000).

As a noted above, the exact mechanisms by which SA affects photochemistry remain obscure. The present paper is the first report on the SA-mediated changes in specific chlorophyll fluorescence parameters. In order to improve our knowledge of barley photosynthetic apparatus in response to SA treatment, the OJIP fluorescence transient was measured in barley plants in responses to different concentrations of SA.

\section{MATERIALS AND METHODS}

\subsection{Plant material and harvest}

The randomly selected healthy seeds of barley (Hordeum vulgare 'Bahman') were sterilized with $5 \%$ sodium hypo-chlorite solution for five minutes prior to sowing. Seeds were then sown on filter paper moistened with distilled water. Ten-day-old seedlings were transferred to modified Hoagland nutrient solution (Johnson et al. 1957) containing $6 \mathrm{mM} \mathrm{KNO}_{3}, 4 \mathrm{mM}$ $\mathrm{Ca}\left(\mathrm{NO}_{3}\right)_{2}, 2 \mathrm{mM} \mathrm{NH} \mathrm{H}_{2} \mathrm{HO}_{4}, 1 \mathrm{mM} \mathrm{MgSO} \mathrm{Mg}_{4}, 50 \mu \mathrm{M}$ $\mathrm{H}_{3} \mathrm{BO}_{3}, 2 \mu \mathrm{M} \mathrm{MnSO}_{4}, 2 \mu \mathrm{M} \mathrm{ZnSO}_{4}, 0.5 \mu \mathrm{M} \mathrm{CuSO}_{4}, 0.5$ $\mu \mathrm{M} \mathrm{H}_{2} \mathrm{MoO}_{4}$ and $0.02 \mathrm{mM} \mathrm{FeSO}$-EDTA for 15 days prior to the start of treatments. The $\mathrm{pH}$ of the nutrient medium was adjusted to 5.5-5.7. The seedlings were grown in a controlled growth room under a 16/8 light/dark cycle and a photosynthetically active radiation (PAR) of $200 \pm 30 \mu \mathrm{mol} \mathrm{m}^{-2} \mathrm{~s}^{-1}$ and an average day/night temperature of $25 \pm 1 / 18 \pm 1{ }^{\circ} \mathrm{C}$. Salicylic acid (SA) was dissolved in absolute ethanol then added drop wise to water (ethanol/water: $1 / 1000 \mathrm{v} / \mathrm{v}, \mathrm{pH}$ was adjusted to 5.7) (Williams et al. 2003). At 25 days after germination, the foliar application of SA was carried out in the morning (between 08:00 and 10:00) with a compression sprayer of 1 L capacity. Non-SA applied plants were sprayed with ethanol/water $(1 / 1000 \mathrm{v} / \mathrm{v})$. At 1 and 5 days after treatment, the plants were harvested and the recent fully expanded and mature leaves were used for measurement of chlorophyll fluorescence and other analysis.

\subsection{Chlorophyll $a$ fluorescence measurements}

Chlorophyll $a$ fluorescence transients (OJIP transients) were measured with a Packet-PEA chlorophyll fluorimeter (Plant Efficiency Analyser, Hansatech Instruments Ltd., King's Lynn, Norfolk, PE 32 1JL, England) in dark-adapted (for at least $20 \mathrm{~min}$ ) leaves of barley. We used the JIP-test (Strasser and Strasser, 
1995; Strasser et al., 2004) to analyse chlorophyll a fluorescence rises. The measured and calculated parameters are described in Tab 1. Specific parameters were calculated from energy fluxes for light absorption
(ABS), trapping (TR) of excitation energy and electron transport (ETR) per reaction center (RC) or per sample area called cross-section (CS).

Table 1: Some groups of measured and calculated parameters using the JIP-test (Yusuf et al., 2010)

\begin{tabular}{|c|c|}
\hline Nomenclature & Explanation \\
\hline \multicolumn{2}{|c|}{ Data extracted from the recorded fluorescence transient OJIP } \\
\hline Area & $\begin{array}{l}\text { Total complementary area between } F_{\mathrm{o}} \text { and } F_{\mathrm{m}} \text { (reflecting the size of the } \\
\text { plastoquinone pool) }\end{array}$ \\
\hline$F_{\mathrm{J}}$ & Fluorescence intensity at the $J$-step ( $2 \mathrm{~ms}$ ) of $O J I P$ \\
\hline$F_{\mathrm{I}}$ & Fluorescence intensity at the $I$-step $(30 \mathrm{~ms})$ of $O J I P$ \\
\hline \multicolumn{2}{|c|}{ Fluorescence parameters derived from the extracted data } \\
\hline$F_{\mathrm{m}}$ or $F_{\max }$ & $\begin{array}{l}\text { Maximal chlorophyll fluorescence intensity measured when all photosystem II } \\
\text { (PSII) reaction centers are closed }\end{array}$ \\
\hline$F_{\mathrm{o}}$ & Minimal fluorescence (all PSII RCs are assumed to be open) \\
\hline$F_{\mathrm{v}}$ & Variable chlorophyll fluorescence $\left(F_{\mathrm{m}}-F_{\mathrm{o}}\right)$ \\
\hline$V_{\mathrm{j}}$ & $\begin{array}{l}\text { Relative variable fluorescence at time } J \text { (relative variable fluorescence at phase } J \\
\text { of the fluorescence induction curve }\end{array}$ \\
\hline \multicolumn{2}{|c|}{ The specific energy fluxes (per reaction center, $R C$ ) } \\
\hline $\mathrm{ABS} / \mathrm{RC}$ & Light absorption flux (for PSII antenna chlorophylls) per RC \\
\hline $\mathrm{DI} / \mathrm{RC}$ & Dissipation energy flux per RC \\
\hline $\mathrm{ET} / \mathrm{RC}$ & Maximum electron transport flux (further than $\mathrm{Q}_{\mathrm{A}}{ }^{-}$) per $\mathrm{RC}$ \\
\hline $\mathrm{TR} / \mathrm{RC}$ & Trapped (maximum) energy flux (leading to $\mathrm{Q}_{\mathrm{A}}$ reduction) per $\mathrm{RC}$ \\
\hline \multicolumn{2}{|c|}{ The phenomenological energy fluxes (per excited cross-section of leaf, CS) } \\
\hline $\mathrm{ABS} / \mathrm{CS}$ & Absorbed photon flux per cross section \\
\hline TR/CS & Maximum trapped excitation flux per cross section \\
\hline ET/CS & Electron transport flux from $Q_{A}$ to $Q_{B}$ per cross section \\
\hline $\mathrm{DI} / \mathrm{CS}$ & Dissipation energy flux per cross section \\
\hline \multicolumn{2}{|c|}{ Quantum yields and efficiencies } \\
\hline$\varphi \mathrm{E}_{\mathrm{o}}$ or phi $\left(\mathrm{E}_{\mathrm{o}}\right)=\mathrm{ET}_{\mathrm{o}} / \mathrm{ABS}$ & Quantum yield for electron transport (ET) \\
\hline \multicolumn{2}{|c|}{ De-excitation rate constants of PSII antenna } \\
\hline$k_{\mathrm{N}}$ & Non-photochemical de-excitation rate constant \\
\hline$k_{\mathrm{P}}$ & Photochemical de-excitation rate constant \\
\hline \multicolumn{2}{|l|}{ Performance index } \\
\hline $\mathrm{PI}_{\mathrm{ABS}}$ & $\begin{array}{l}\text { The performance index that is calculated as: }(\mathrm{RC} / \mathrm{ABS}) \times\left(\varphi_{\mathrm{Po}} /\left(1-\varphi_{\mathrm{Po}}\right)\right) \times\left(\psi_{\mathrm{o}} /(1-\right. \\
\left.\left.\psi_{\mathrm{o}}\right)\right) \text {, where, RC is for reaction center; ABS is for absorption flux; } \varphi_{\mathrm{Po}} \text { is for } \\
\text { maximal quantum yield for primary photochemistry; and } \psi_{\mathrm{o}} \text { is for the quantum } \\
\text { yield for electron transport }\end{array}$ \\
\hline
\end{tabular}

\subsection{Determination of total carotenoids and} chlorophylls $a$ and $b$

Leaf concentrations of chlorophylls and carotenoids were measured after extraction of pigments in the methanol according to Lichtenthaler and Wellburn (1985). The weighed samples were homogenized with homogenizer at $1000 \mathrm{rpm}$ for one minute. The homogenate was filtered, and was centrifuged at 2500 rpm for 15 minutes. The supernatant was separated and the absorbance was read at 400-700 $\mathrm{nm}$ on spectrophotometer. Leaf concentrations of chlorophylls and carotenoids were calculated as:

Chl $a=15.65 \mathrm{~A}_{666}-7.340 \mathrm{~A}_{653}$

Chl $b=27.05 \mathrm{~A}_{653}-11.21 \mathrm{~A}_{666}$
Total carotenoids $=1000 \mathrm{~A}_{470}-2.860 \mathrm{Chl} a-129.2$ Chlb/245

\subsection{Statistical analysis}

Experiments were performed in complete randomized block design. All data satisfied the assumption for ANOVA for normal distribution and homogeneity of variance. Chlorophyll fluorescence were done on 20 plants from each treatment, and 3 replicates for each plant $(n=60)$ while the other measurements were performed on 4 plants from each treatment and we had one replicate for each plant $(n=4)$. Statistical analysis was carried out using Sigma Stat (3.5) with Tukey test $(\mathrm{P}<0.05)$. Correlation analysis using Spearman Rank Order Correlation in Sigma Stat was done to determine the relationship between $\mathrm{PI}_{\mathrm{ABS}}$ and leaf carotenoids. 


\section{RESULTS AND DISCUSSION}

We found that the low concentration of SA $(0.5 \mathrm{mM})$ caused a significant increase in $\mathrm{Chl} b$ and carotenoid content compared with the control (Fig. 1). Our results are in line with the findings of Singh and Usha (2003), and Javaheri et al. (2012), who observed that the treatment with low SA increases photosynthetic pigment contents in some plants under normal or stress conditions. In the present study, treatment with higher concentration of SA $(5 \mathrm{mM})$ resulted in a lower total $\mathrm{Chl}$ and carotenoid content as compared to the control. In agreement with our results, Chandra and Bhatt (1998), Moharekar et al. (2003) and Hayat et al. (2010) reported that high SA concentrations (1-5 mM) induced a reduction of chlorophyll contents in wheat and Arabidopsis.

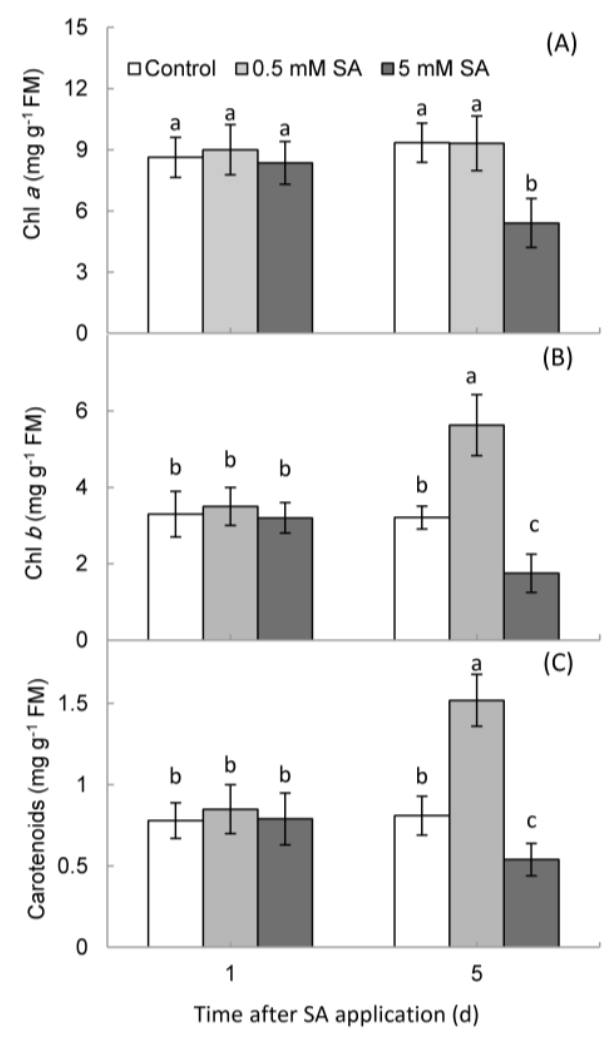

Figure 1: Effects of SA concentrations $(0.5$ and $5 \mathrm{mM})$ on the concentration of chlorophyll $a$ (A), chlorophyll $b$ (B) and total carotenoids $(\mathrm{C})$ at different time intervals after treatment in barley plants. Bars indicated with the same letter are not significantly different $(\mathrm{p}<0.05)$. Values are the mean $\pm \operatorname{SD}(\mathrm{n}=4)$

In present experiment, chlorophyll $a$ fluorescence signals were measured by using the 'JIP-test' (Strasser et al., 2000, 2004), in order to analyse the responses of the photosynthetic apparatus and energy flow among PSII in response to SA treatment. After $24 \mathrm{~h}$ of SA treatment, a slight decrease in the IP phase was noticed (Fig. 2). 5 days after $0.5 \mathrm{mM} \mathrm{SA}$ treatment, a much slower fluorescence rise from level " $P$ " to a " $P$ " level (or $F_{\mathrm{m}}$ ) was observed, which coincided with a large increase in $F_{\mathrm{o}}$ fluorescence (Fig. 3), due to the structural damage leading to decreased excitation energy transfer from the antenna to the reaction center (Kalaji et al., 2011). Under these conditions, an upregulation of $O J$ phase was detected. This higher $O J$ phase rise is closely related to the increased photo-reduction of $\mathrm{Q}_{\mathrm{A}}$ in the active PSII centers (Stirbet and Jee, 2011, 2012), mainly because of a blockage of electron flow. 
High salicylic acid concentration alters the electron flow associated with photosystem II in barley

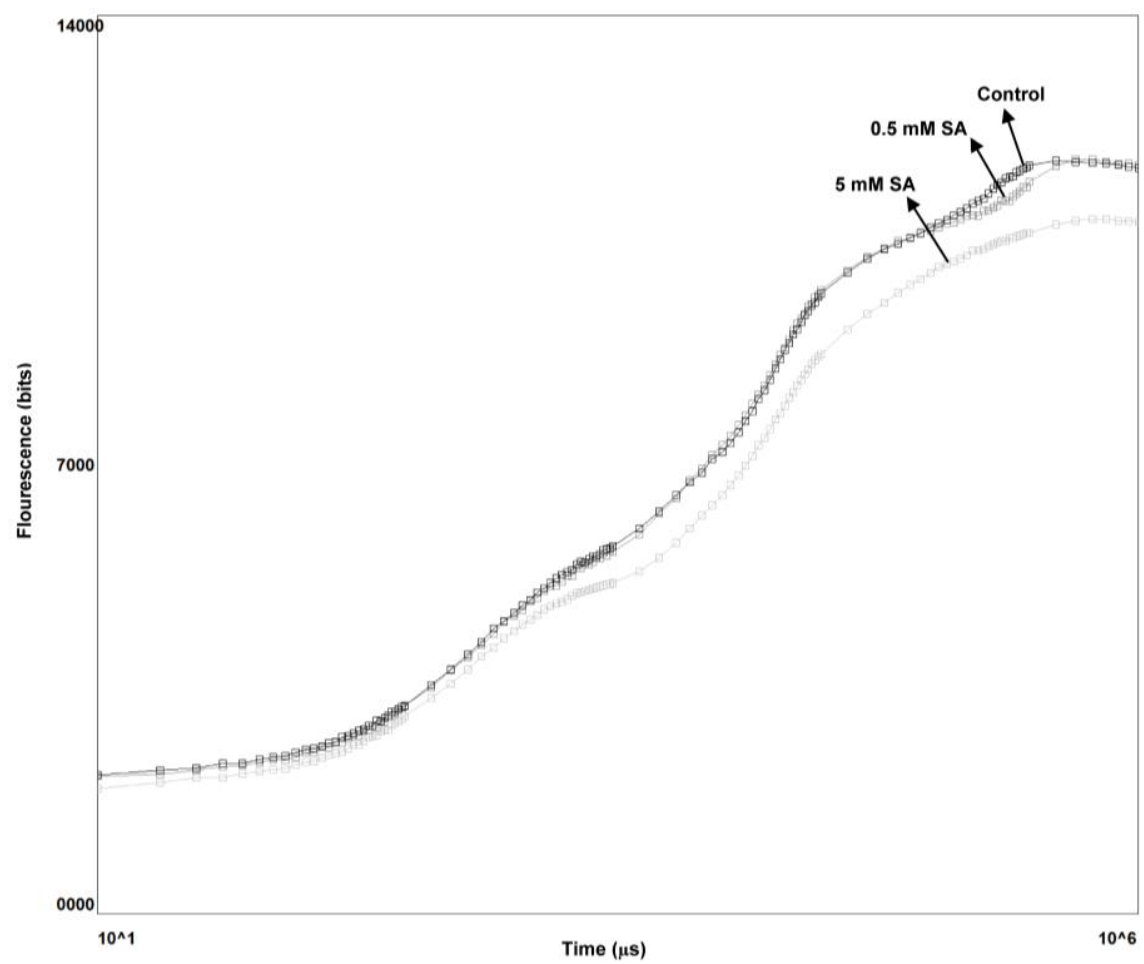

Figure 2: Chlorophyll $a$ fluorescence induction curve of barley seedlings grown under $0 \mathrm{mM}$ (Control), $0.5 \mathrm{mM}$ and $5 \mathrm{mM}$ SA for $24 \mathrm{~h}$

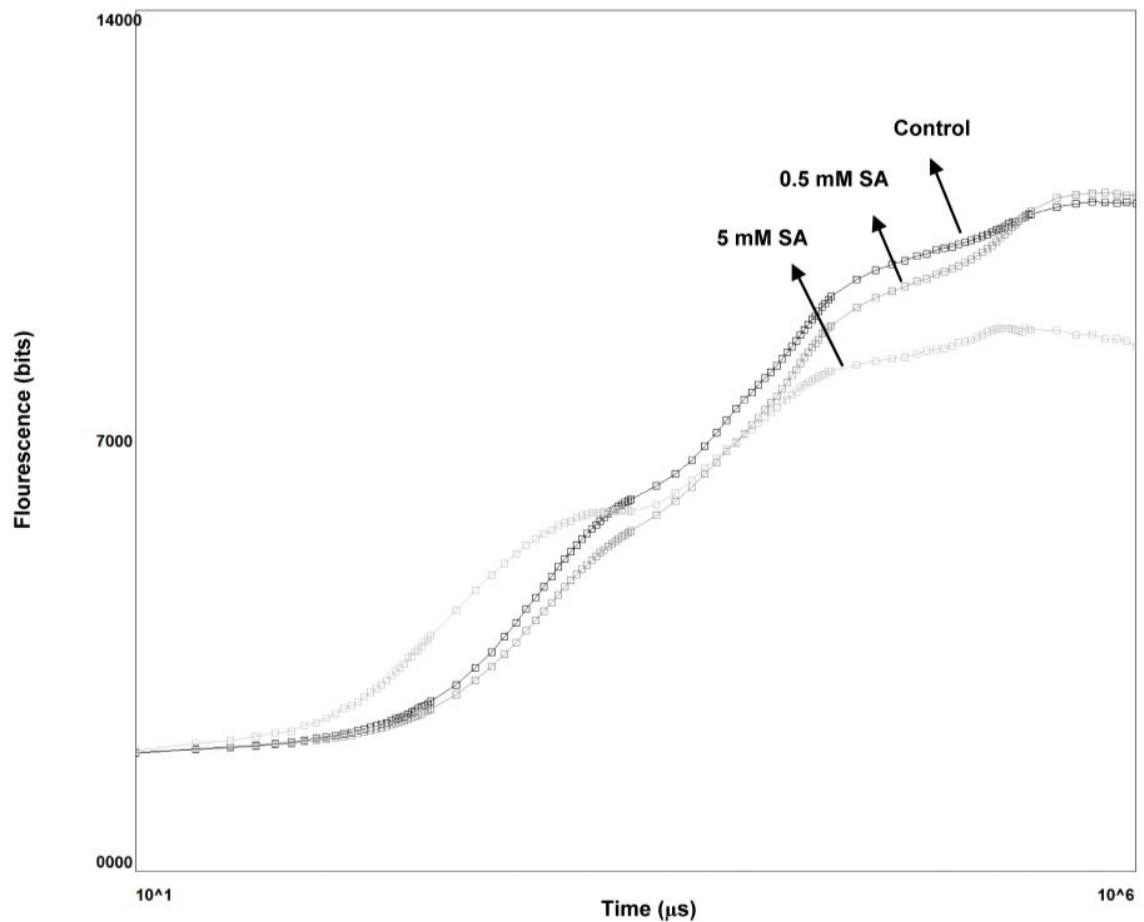

Figure 3: Chlorophyll $a$ fluorescence induction curve of barley seedlings grown under $0 \mathrm{mM}$ (Control), $0.5 \mathrm{mM}$ and $5 \mathrm{mM}$ SA for 5 days 
After $24 \mathrm{~h}$ of SA treatment, the values of the maximal quantum efficiency of PSII $\left(F_{\mathrm{v}} / F_{\mathrm{m}}\right)$ and the efficiency of the water-splitting complex on the donor side of PSII (as inferred from $F_{\mathrm{v}} / F_{\mathrm{o}}$ ) were similar to those of control plants (Fig. 4 and 5). But after 5 days of $0.5 \mathrm{mM} \mathrm{SA}$ treatment, an increase in the PSII function, as estimated by a large increase in performance index $\left(\mathrm{PI}_{\mathrm{ABS}}\right)$, was obtained (Fig. 4 and 6). Carotenoids play an important role in photosynthesis and photoprotection (Cazzonelli and Pogson, 2010; Habibi and Ajory, 2015). Accordingly, we suggest that the increase in $\mathrm{PI}_{\mathrm{ABS}}$, after 5 days of treatment at $0.5 \mathrm{mM} \mathrm{SA}$, was associated with the increased $\mathrm{Chl} b$ and carotenoid levels. Indeed, the accumulation of carotenoids by $0.5 \mathrm{mM} \mathrm{SA}$ foliar spray in barley plants; helped them to maintain higher rates of photosynthesis and photosystem II activity (Dong et al., 2013; Habibi and Ajory, 2015).

In contrary, the decreased $F_{\mathrm{v}} / F_{\mathrm{m}}$ and $\mathrm{PI}_{\mathrm{ABS}}$ in plants treated with $5 \mathrm{mM} \mathrm{SA}$ indicated that the high concentration of SA induced damage to photosynthesis, which is agreement with the findings of Chen et al. (2016) in wheat. This decrease in $\mathrm{PI}_{\mathrm{ABS}}$ is coupled with lower levels of $\mathrm{Chl} b$ and carotenoids. In confirmation of this, there was a significant correlation $(r=0.84$, $\mathrm{p}<0.01$ ) between $\mathrm{PI}_{\mathrm{ABS}}$ and carotenoid level in SAsupplied plants (Fig. 7). Additionally, this downregulation of $F_{\mathrm{v}} / F_{\mathrm{m}}$ and $\mathrm{PI}_{\mathrm{ABS}}$ was associated with decreases in electron transport flux per chlorophyll $\left(\varphi \mathrm{E}_{\mathrm{o}}\right)$ and in efficiency of the water-splitting complex on the donor side of PSII $\left(F_{\mathrm{v}} / F_{\mathrm{o}}\right)$ (Fig. 6), which might be related to the photosynthetic electron transport impairment (Pereira et al., 2000). In addition, we suggest that the increased accumulation of inactive reaction centers was due to the significantly higher values of the efficiency of non-photochemical deexcitation processes $\left(K_{\mathrm{N}}\right)$ (Kalaji et al., 2011). After 5 days of $5 \mathrm{mM}$ SA application, the specific flux of energy (DIo/RC; dissipative energy flux per reaction center and $\mathrm{ABS} / \mathrm{RC}$; the absorption flux per reaction center) parameters were much higher than those determined in control plants (Fig. 6). Thus, the increase in $\mathrm{ABS} / \mathrm{RC}$ might represent a compensatory mechanism (van Heerden et al., 2007) for maintaining electron transport flux per remaining active reaction centers. The specific rate of the electron transport from $Q_{A}$ to $Q_{B}$, depends on the $V_{\mathrm{J}}$ (relative variable fluorescence at time $J$ ) value (Stirbet and Jee, 2011), and this parameter was significantly increased after 5 days of $5 \mathrm{mM}$ SA application in the present study.

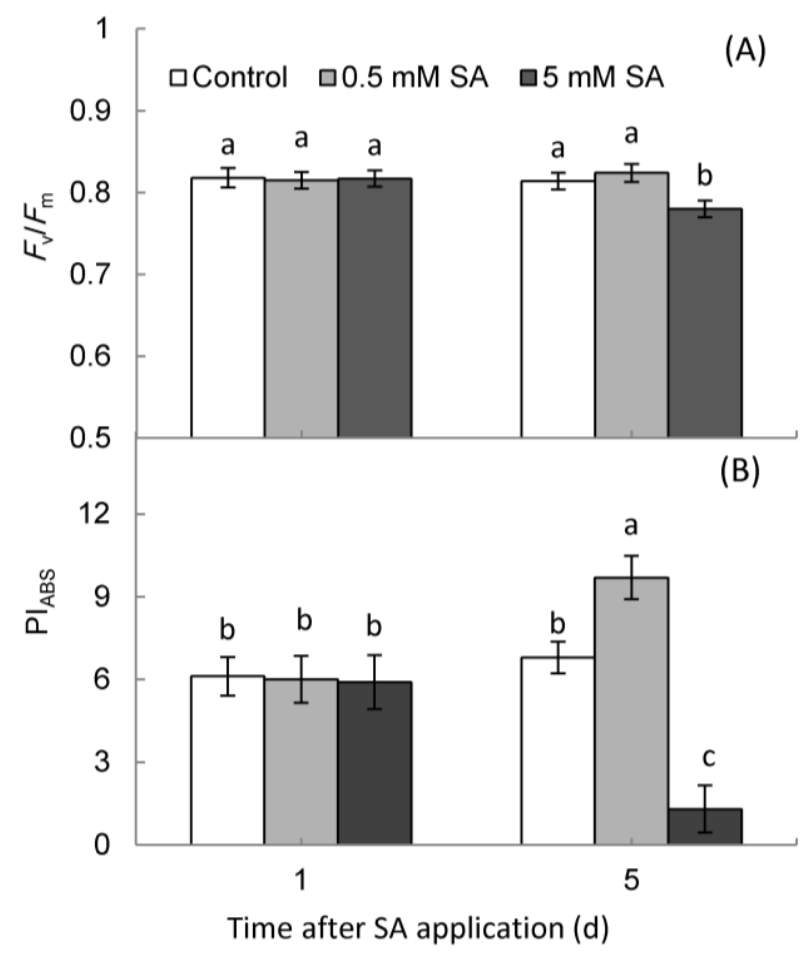

Figure 4: Effects of SA concentrations on the maximum quantum yield of PSII $\left(F_{\mathrm{v}} / F_{\mathrm{m}}\right)$ (A) and the Performance Indexes $\left(\mathrm{PI}_{\mathrm{ABS}}\right)(\mathrm{B})$ at different time intervals after treatment in barley plants. Bars indicated with the same letter are not significantly different $(\mathrm{p}<0.05)$ 


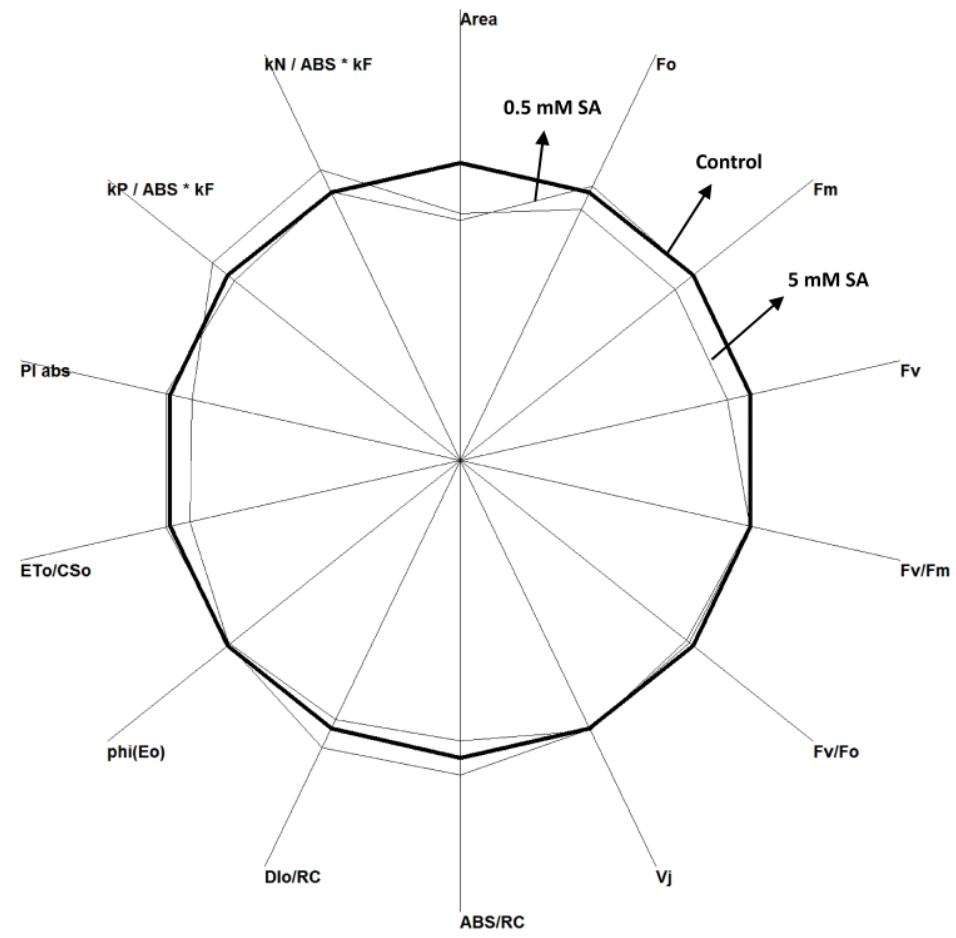

Figure 5: A 'spider plot' of selected parameters characterizing behavior of photosystem II of barley leaves exposed $24 \mathrm{~h}$ to $0 \mathrm{mM}$ (Control), $0.5 \mathrm{mM}$ and $5 \mathrm{mM} \mathrm{SA}$ (See Tab 1 for the meaning of the parameters)

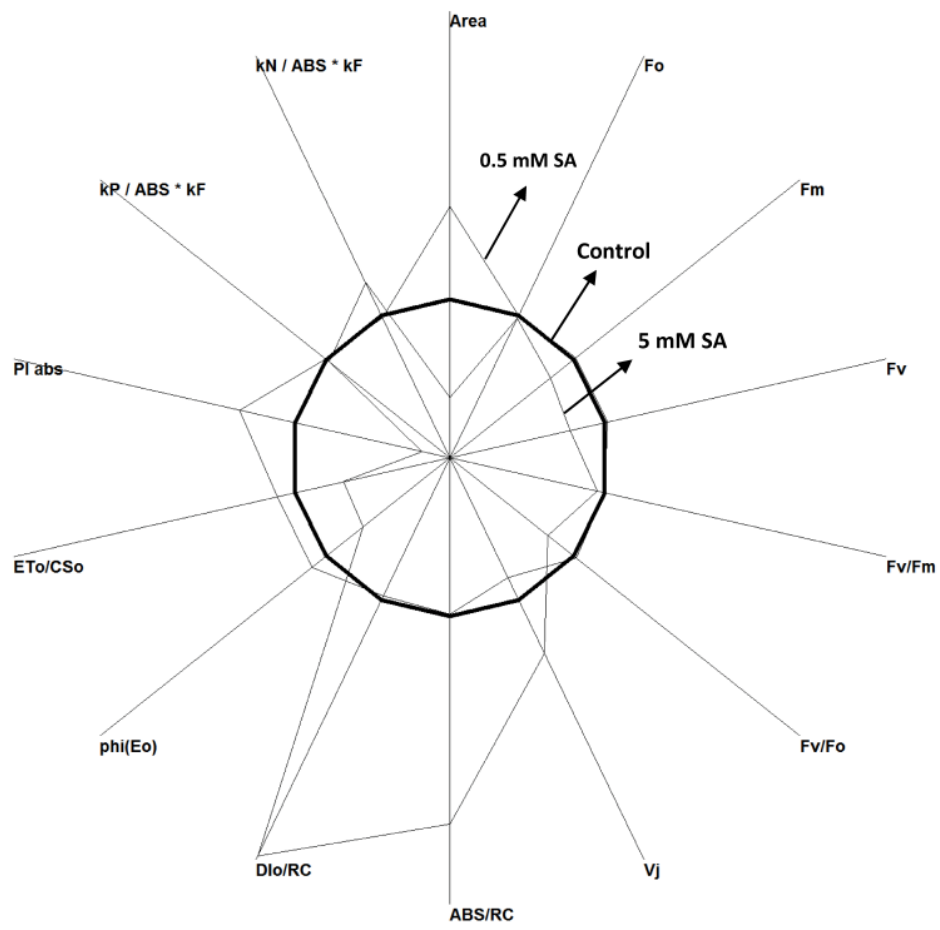

Figure 6: A 'spider plot' of selected parameters characterizing behavior of photosystem II of barley leaves exposed 5 days to $0 \mathrm{mM}$ (Control), $0.5 \mathrm{mM}$ and $5 \mathrm{mM} \mathrm{SA}$ (See Tab 1 for the meaning of the parameters) 


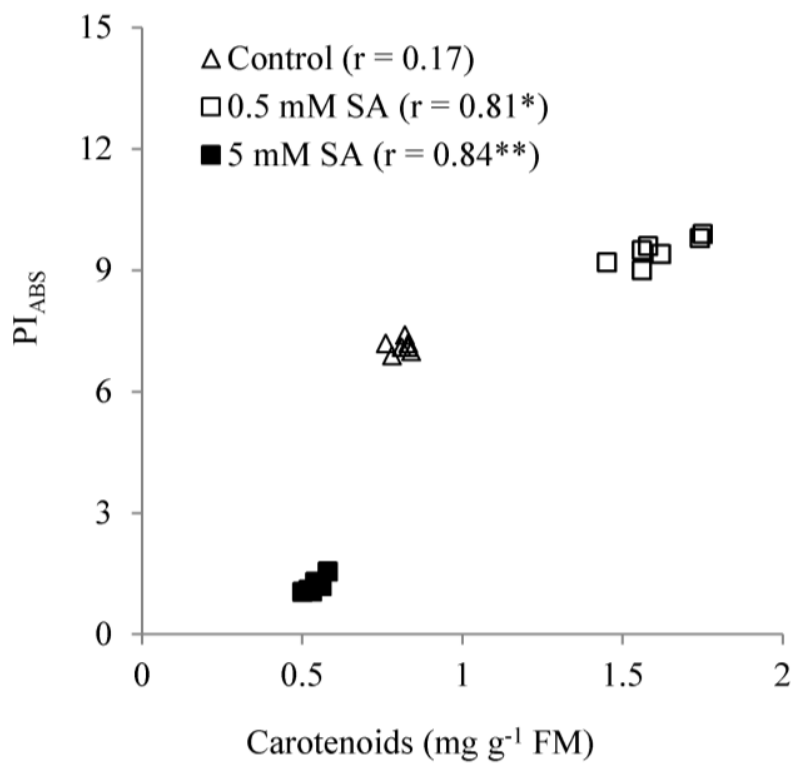

Figure 7: Correlations between the Performance Indexes $\left(\mathrm{PI}_{\mathrm{ABS}}\right)$ and the leaf carotenoids levels in barley plants grown for 5 days under $0 \mathrm{mM}$ (Control), $0.5 \mathrm{mM}$ and $5 \mathrm{mM} \mathrm{SA}$ treatment: $\mathrm{ns}$, *, and **: non-significant, significant at the $5 \%$ and $1 \%$ levels of probability, respectively

In conclusion, SA at low concentration improved the efficiency and the yield of energy transfer and primary photochemistry in barley seedlings as related to the higher levels of $\mathrm{Chl} b$ and carotenoids. In contrary, several parameters related to PSII activity (e.g., the time needed to reach the maximal chlorophyll fluorescence, the variable fluorescence, the inferred oxygen evolving complex activity, the electron transport flux, and the calculated Performance Index) were significantly decreased by SA application at high concentration indicating that the high concentration of SA induced damage to photosynthesis. On the other hand, increasing the photosynthetic activity of barley plants at low SA concentration can help for crop research and practical applications in order to improve crop productivity and increase plant nutritional value for a growing world population.

\section{REFERENCES}

Arfan, M., Athar. H. R., Ashraf, M. (2007) Does exogenous application of salicylic acid through the rooting medium modulate growth and photosynthetic capacity in two differently adapted spring wheat cultivars under salt stress? Journal of Plant Physiology, 164,685-694. doi:10.1016/j.jplph.2006.05.010

Azzabi, G., Pinnola, A., Betterle, N., Bassi, R., Alboresi, A. (2012) Enhancement of nonphotochemical quenching in the bryophyte Physcomitrella patens during acclimation to salt and osmotic stress. Plant Cell Physiology, 53(10),1815-1825. doi:10.1093/pcp/pcs124

Bussotti, F., Strasser, R. J., Schaub, M. (2007) Photosynthetic behavior of woody species under high ozone exposure probed with the JIP-test: a review. Environmental Pollution, 147(3),430-437. doi:10.1016/j.envpol.2006.08.036

Chandra, A., Bhatt, R.K. (1998) Biochemical and physiological response to salicylic acid in relation to the systemic acquired resistance. Photosynthetica, 35(2),255-258. doi:10.1023/A:1006966908357

Chen, Y.E., Cui, J.M., Li, G.X., Yuan, M., Zhang, Z.W., Yuan, S., Zhang, H.Y. (2016) Effect of salicylic acid on the antioxidant system and photosystem II in wheat seedlings. Biologia Plantarum, 60(1),139147. doi:10.1007/s10535-015-0564-4

Dong, J.Z., Wang, Y., Wang, S.H., Yin, L.P., Xu, G.J., Zheng, C., Lei, C., Zhang, M.Z. (2013) Selenium increases chlorogenic acid, chlorophyll and carotenoids of Lycium chinense leaves. Journal of 
High salicylic acid concentration alters the electron flow associated with photosystem II in barley

the Science of Food and Agriculture, 93(2),310315. doi:10.1002/jsfa.5758

Habibi, G., Ajory, N. (2015) The effect of drought on photosynthetic plasticity in Marrubium vulgare plants growing at low and high altitudes. Journal of Plant Research, 128(6),987-994. doi:10.1007/s10265-015-0748-1

Hamdani, S., Qu, M., Xin, C.P., Li, M., Chu, C., Zhu, X.G. (2015) Variations between the photosynthetic properties of elite and landrace Chinese rice cultivars revealed by simultaneous measurements of $820 \mathrm{~nm}$ transmission signal and chlorophyll $a$ fluorescence induction. Journal of Plant Physiology, 177,128-138. doi:10.1016/j.jplph.2014.12.019

Hara, M, Furukawa, J., Sato, A., Mizoguchi, T., Miura, K. (2012) Abiotic stress and role of salicylic acid in plants. In: Abiotic Stress Responses in Plants. Springer, New York, pp 235-251. doi:10.1007/9781-4614-0634-1_13

Hasanuzzaman, M., Nahar, K., Fujita, M. (2013) Plant response to salt stress and role of exogenous protectants to mitigate salt-induced damages. In: Ecophysiology and Responses of Plants under Salt Stress. Springer, New York, pp 25-87. doi:10.1007/978-1-4614-4747-4_2

Hayat, Q., Hayat, S., Irfan, M., Ahmad, A. (2010) Effect of exogenous salicylic acid under changing environment: a review. Environmental and Experimental Botany, 68(1),14-25. doi:10.1016/j.envexpbot.2009.08.005

Janda, M., Ruelland, E. (2015) Magical mystery tour: salicylic acid signalling. Environmental and Experimental Botany, 114,117-128. doi:10.1016/j.envexpbot.2014.07.003

Javaheri, M., Mashayekhi, K., Dadkhah, A., Tavallaee, F.Z. (2012) Effects of salicylic acid on yield and quality characters of tomato fruit (Lycopersicum esculentum Mill.). International Journal of Agriculture and Crop Sciences, 4,1184-1187.

Jee, G. (1995) Sixty-Three Years Since Kautsky: Chlorophylla Fluorescence. Australian Journal of Plant Physiology, 22,131-160. doi:10.1071/PP9950131

Johnson, C.M., Stout, P.R., Broyer, T.C., Carlton, A.B. (1957) Comparative chlorine requirements of different plant species. Plant Soil, 8(4),337-353. doi:10.1007/BF01666323

Kalaji, H.M., Bosa, K., Kościelniak, J., ŻukGołaszewska, K. (2011) Effects of salt stress on photosystem II efficiency and $\mathrm{CO}_{2}$ assimilation of two Syrian barley landraces. Environmental and
Experimental Botany, 73,64-72. doi:10.1016/j.envexpbot.2010.10.009

Khan, M.I.R., Asgher, M., Khan, N.A. (2014) Alleviation of salt-induced photosynthesis and growth inhibition by salicylic acid involves glycinebetaine and ethylene in mungbean (Vigna radiata L.). Plant Physiology and Biochemistry, 80,67-74. doi:10.1016/j.plaphy.2014.03.026

Lichtenthaler, H.K., Wellburn, A.R. (1983) Determinations of total carotenoids and chlorophylls $a$ and $b$ of leaf extracts in different solvents. Biochemical Society Transactions, 11(5),591-592. doi:10.1042/bst0110591

Li, T., Hu, Y., Du, X., Tang, H., Shen, C., Wu, J. (2014) Salicylic acid alleviates the adverse effects of salt stress in Torreya grandis cv. Merrillii seedlings by activating photosynthesis and enhancing antioxidant systems. PloS one 9(10),p.e109492. doi:10.1371/journal.pone.0109492

Miura, K., Tada, Y. (2014) Regulation of water, salinity, and cold stress responses by salicylic acid. Frontiers in Plant Science, 5, p.4. doi:10.3389/fpls.2014.00004

Moharekar, S.T., Lokhande, S.D., Hara, T., Tanaka, R., Tanaka, A., Chavan, P.D. (2003) Effect of salicylic acid on chlorophyll and carotenoid contents of wheat and moong seedlings. Photosynthetica, 41(2),315-317. doi:10.1023/B:PHOT.0000011970.62172.15

Pereira, W.E., de Siqueira, D.L., Martínez, C.A., Puiatti, M. (2000) Gas exchange and chlorophyll fluorescence in four citrus rootstocks under aluminium stress. Journal of Plant Physiology, 157(5),513-520. doi:10.1016/S01761617(00)80106-6

Singh, B., Usha, K. (2003) Salicylic acid induced physiological and biochemical changes in wheat seedlings under water stress. Plant Growth Regulation, 39,137-141. doi:10.1023/A:1022556103536

Stirbet, A., jee, G. (2012) Chlorophyll $a$ fluorescence induction: Understanding the thermal phase, the J-I$\mathrm{P}$ rise. Photosynthesis Research, 113,15-61. doi:10.1007/s11120-012-9754-5

Strasser, B.J., Strasser, R.J. (1995) Measuring fast fluorescence transients to address environmental questions: the JIP-test. In: Photosynthesis: from Light to Biosphere. Kluwer academic publishers, Netherlands, pp 977-980. doi:10.1007/978-94-0090173-5_1142

Strasser, R.J., Srivastava, A., Tsimilli-Michael, M. (2000) The fluorescence transient as a tool to 
characterize and screen photosynthetic samples. In: Probing Photosynthesis: Mechanism, Regulation and Adaptation. Taylor and Francis, London, pp 443-480.

Strasser, R.J., Tsimilli-Michael, M., Srivastava, A. (2004) Analysis of the chlorophyll a fluorescence transient. In: Advances in Photosynthesis and Respiration. Chlorophyll a Fluorescence: a Signature of Photosynthesis. Springer, Dordrecht, pp 321-362. doi:10.1007/978-1-4020-3218-9_12

Van Heerden, P.D.R., Swanepoel, J.W., Krüger, G.H.J. (2007) Modulation of photosynthesis by drought in two desert scrub species exhibiting $\mathrm{C}_{3}$-mode $\mathrm{CO}_{2}$ assimilation. Environmental and Experimental Botany, 61(2),124-136.

doi:10.1016/j.envexpbot.2007.05.005
Williams, M., Senaratna, T., Dixon, K., Sivasithamparam, K. (2003) Benzoic acid induces tolerance to biotic stress caused by Phytophthora cinnamomi in Banksia attenuata. Plant Growth Regulation, 41(1),89-91. doi:10.1023/A:1027355604096

Yusuf, M.A., Kumar, D., Rajwanshi, R., Strasser, R.J., Tsimilli-Michael, M., Sarin, N.B. (2010) Overexpression of $\gamma$-tocopherol methyl transferase gene in transgenic Brassica juncea plants alleviates abiotic stress: physiological and chlorophyll a fluorescence measurements. Biochimica et Biophysica Acta, 1797(8),1428-1438. doi:10.1016/j.bbabio.2010.02.002 